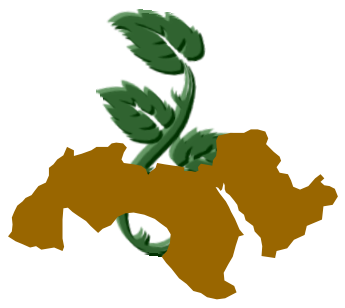

\title{
AGRONOMIC TRAITS AND PROTEIN PATTERNS FOR SOME PROMISING WHEAT SEMIDWARF MUTANT LINES
}

\author{
Sobieh$^{1}$, El-S.S. and M.H. Abou-Deif ${ }^{2}$ \\ 1. Plant Research Dept., Nuclear Research Center, Atomic Energy Authority, Inshas, Egypt \\ 2. Genetics and Cytology Dept., National Research Centre, 12622 Dokki, Cairo, Egypt
}

Keywords: Wheat, Gamma rays, Selection, Mutations, Protein patterns

\section{ABSTRACT}

Two field experiments were carried out to evaluate six mutant lines having a good agronomic potential comparing with their original varieties Sids5, Sids6 and Sids7. The results showed significant decrease in plant height for all semidwarf mutant lines. The reduction of plant height reached to $19.83 \%$ comparing with the original varieties. Some semidwarf mutant lines (line 5-1, line 6-1 and line 7-1) exhibited highly significant values for spike length, number of spikes/plant and grain yield/plant as compared to their original varieties. The original varieties manifested highly significant values for number of grains/spike as compared to their all semidwarf mutant lines. The results indicated that wheat semidwarf mutants of line 5-1, line 6-1 and line 7-1 are promising mutant lines, since they gave high grain yield. All studied genotypes were electrophoreticaly analyzed for grain water-soluble proteins. The discrimination of such mutant lines and their parental varieties revealed differences in their banding patterns and occurrence of genetic variation between such genotypes. The electrophoretic analyses of proteins revealed some newly induced bands such as bands with molecular weights of 114.04, 87.82, 41.55 and $11.90 \mathrm{kDa}$. Such newly bands, which were not existed in the unirradiated varieties, may be originated from gamma radiation effects. It is expected that gamma rays modified the structure of some genes in the mutant lines, and these modifications appeared as absence of protein bands with molecular weights of $72.60 \mathrm{kDa}$ in sids5 and $24.39 \mathrm{kDa}$ in Sids6. The variety Sids7 exhibited the highest numbers of new protein bands after irradiation. The results revealed positive relations
\end{abstract}

between number of bands in the protein patterns of Sids5 and Sids6 and their mutant lines, and for most of agronomic and yield traits.

\section{INTRODUCTION}

Chemical and physical mutagenesis (irradiation), were used widely for producing mutations that increase genetic variability in target materials. It is well known that mutagens could directly induce physiological changes, point mutations and chromosomal aberrations. Different plant varieties of the same species showed different responses to radiation with respect to their morphological and genetic structure at protein level. Mutation breeding is the use of radiation to create mutations in the genes of crop plants then to select valuable lines with desirable traits (Scoles, 1999). Mutations induced by ionizing radiation inactivate genes leading to altered metabolic pathways or repressors whose absence leads to enhance production of metabolites improving varieties (Little, 2002). During the past seventy years, worldwide more than 2252 mutant varieties have been officially released. Mutation induction with radiation was the most frequently used method to develop direct mutant varieties (89\%). Gamma rays were employed to develop $64 \%$ of the radiation induced mutant varieties, followed by X-rays (22\%). 197 mutant varieties of bread wheat have been released with improved characters such as earliness, grain quality, improved grain yield, shortness, semidwarf, disease resistance and drought tolerance (Muluszynski et al 2002). Sakin et al (2004) found several mutant lines; have desirable characters, with higher or lower means than those of mother cultivars.

Certain types of stressful environmental conditions can activate stress genes to produce stress 
proteins that enable organisms to tolerate such stresses. Biochemical markers have been used to distinguish between homozygous and heterozygous individuals and to estimate the level of genetic variability in plant populations (Melchinger $\boldsymbol{e t}$ al 1992). Hussien and Stegemann (1978) reported that sodium dodecyl sulphate-polyacrylamide gel electrophoresis (SDS-PAGE) of total grain proteins was a rapid method to screen varietals differences in wheat. Vombergar et al (1984) reported differences in the electrophoregrams of 14 winter wheat cultivars as no two cultivars produced identical patterns of proteins. Abdel-Tawab et al (1993) classified twelve cultivars of wheat into different groups according to their performance as revealed by their electrophoretic analysis based on protein zymograms. Selim (2000) demonstrated that seed protein profiles may be serving as a useful tool for wheat varieties identification.

The aim of this study is to evaluate six wheat mutant lines having good agronomic potential comparing with their original parents Sids5, Sids6 and Sids7. Also, to study effect of gamma irradiation on grain protein patterns to distinguish between the induced mutant lines and their parental varieties.

\section{MATERIALS AND METHODS}

\section{Field experiment}

Three hexaploid wheat varieties (Triticum aestivum L.) Sids5, Sids6 and Sids7 besides six driven mutants, were used in this study. Two field experiments were carried out in the experimental farm belonging to the Plant Research Department, Nuclear Research Center at Inshas during two successive growing seasons of 2003/2004 and $2004 / 2005$ to evaluate six semidwarf mutant lines; 5-1, 5-2, 6-1, 6-2, 7-1 and 7-2. These mutants were selected, from the bread wheat varieties
Sids5, Sids6 and Sids 7 after irradiation by 250 Gy (Sobieh, 2002), and examined for yield and its attributes. The physical and chemical properties of used soil in the experiment are shown in Table (1).

Randomized complete block design with three replicates were applied. Each plot consisted of 10 rows, 3 meters long and $20 \mathrm{~cm}$ apart. Grains were sown at space of $10 \mathrm{~cm}$ apart within the row. 240 $\mathrm{kg} /$ hectare of ammonium nitrate fertilizer (33.5\%) was added on three doses; $20 \%$ before sowing, $40 \%$ after 21 days of sowing and $40 \%$ before heading. Super phosphate $15.5 \%$ and potassium sulphate $48 \%$ fertilizers were added at rate of 240 and $120 \mathrm{~kg} / \mathrm{hectare}$ respectively before sowing. The other cultural practices were done as in the ordinary fields.

The following traits were estimated on thirty individual plants were taken randomly from each plot; (1) plant height $(\mathrm{cm}),(2)$ spike length $(\mathrm{cm})$, (3) number of spikes/plant, (4) number of grains/spike, (5) 1000-grain weight (gm), and (6) grain yield/plant (gm). The data obtained were subjected to statistical analysis (Snedecor and Cochran 1969). The L.S.D. test was used for comparison between mean values (Waller and Duncan 1969).

\section{Protein electrophoresis}

Samples of $1 \mathrm{~g}$ kernel flour from the wheat varieties that were exposed to gamma-rays, in addition, unirradiated plants as controls, were used for protein analysis. SDS-PAGE analysis was performed (Laemmli, 1970). The sample preparation and extraction of water-soluble proteins were performed (Stegemann et al 1980). Gels were photographed and scanned by Phoretix 1D Quantifier, Image Analysis Software, England Imaging System, Epson GT 9500 Scanner.

Table 1. Physical and chemical properties of Inshas soil.

\begin{tabular}{|c|c|c|c|c|c|c|}
\hline \multicolumn{3}{|c|}{ Particles size distribution (\%) } & \multirow{2}{*}{$\begin{array}{c}\text { Texture } \\
\text { class }\end{array}$} & \multirow{2}{*}{$\begin{array}{c}\mathrm{CaCO}_{3} \\
\%\end{array}$} & \multirow{2}{*}{$\begin{array}{c}\mathrm{pH} \\
1: 2.5\end{array}$} & \multirow{2}{*}{$\begin{array}{l}\text { Ece } \\
\mathrm{dS} / \mathrm{m}\end{array}$} \\
\hline Sand $\%$ & Silt $\%$ & Clay $\%$ & & & & \\
\hline 91.4 & 5.5 & 3.1 & Sandy & 1.05 & 7.9 & 0.8 \\
\hline
\end{tabular}




\section{RESULTS AND DISCUSSION}

\section{Yield and its components}

Mean squares from analysis of variance for yield and its attributes of the nine wheat genotypes are shown in Table (2). The results showed significant differences among genotypes in the two seasons as well as in the combined analysis of the two seasons.

The results of combined analysis over two seasons, as shown in Table (3) and Figures (1) and (2), showed that plant height mean was $78.1 \mathrm{~cm}$ in mutant line 7-2 compared to $97.4 \mathrm{~cm}$ in its parent Sids7, also the plant height of Sids6 was reduced from 98.9 to $78.4 \mathrm{~cm}$ in mutant line $6-1$. The ratios of reduction were $19.81 \%$ and $20.73 \%$ in the two previous mutants, respectively. Spike length was $19.18,18.45$ and $18.48 \mathrm{~cm}$ in the three varieties Sids5, Sids6 and Sids7, respectively. On the other hand, it ranged from 18.55 to $20.51 \mathrm{~cm}$ in the mutant lines. Three semidwarf mutant lines 5-1, 6-1 and 7-1 exceeded their parental varieties by percentage ratios of $6.93,10.29$ and $10.98 \%$, respectively.

The mutant lines 5-1, 6-1 and 7-1 manifested number of spikes per plant extremely higher than those of their original parents Sids5, Sids6 and Sids7, respectively. Meanwhile, the mutant lines 5-2, 6-2 and 7-2 had number of spikes per plant slightly higher than those in the parental varieties as shown in the combined analysis over the two seasons. Number of grains per spike ranged from 88.79 (mutant 5-2) to 101.5 (mutant 7-1) compared to 112.83 (Sids6) to 113.83 (Sids7) in the combined analysis (Table 3). It is clear that the original varieties had number of grains per spike exceeded the mutants.

1000 -grain weight ranged from 56 to $63.16 \mathrm{~g}$ in the mutant lines comparing to 56.33 to $59.66 \mathrm{~g}$ in the parental varieties in combined analysis over the two seasons. Grain yield per plant ranged from $18.54 \mathrm{~g}$ (line 5-2) to $58.61 \mathrm{~g}$ (line 7-1) in the mutant lines compared to $16.96 \mathrm{~g}$ (Sids6) to $20.10 \mathrm{~g}$
(Sids5). The mutant lines of 5-1, 6-1 and 7-1 exceeded their parental varieties significantly in grain yield per plant by 171.04, 132.31 and $205.10 \%$, respectively. In contrast, the mutant lines 5-2, 6-2 and 7-2 showed lower values than the parental varieties (Table 3). The mutants of high grain yield (line 5-1, line 6-1 and line 7-1) can be used directly as new cultivars.

The results showed that the ratio of reduction in plant height was $19.81 \%$ and $20.73 \%$ in the two mutants 7-2 and 6-1, respectively. Similar results were obtained by Sobieh (2002). The three semidwarf mutants 5-1, 6-1 and 7-1 exceeded their parental varieties in spike length, number of spikes per plant, weight of 1000 grains and grain yield per plant. These results are in agreement with those of Santana \& Cervantes (1996); AlKobaisi et al (1997); Gheorghe \& Burloi (1992), Camargo et al (1997) and Tulmann et al (2001). On the other hand, the original varieties had number of grains per spike exceeded the mutants. This result coincided with that obtained by Santana and Cervants (1996).

\section{Effect of irradiation on protein electropho- retic patterns}

The electrophoretic patterns for grain watersoluble proteins of the three wheat varieties Sids5, Sids6 and Sids 7 as well as their mutant lines 5-1, 5-2, 6-1, 6-2, 7-1 and 7-2 after irradiation using $\gamma-$ rays of 250 Gy are shown in Figure (3) and Table (4). Great differences between the three varieties and their mutants in band number and loci were revealed, where some new bands appeared and others disappeared in the patterns of plants. The variety Sids 5 manifested 15 bands in unirradiated plants, while it showed 16 bands in mutant 5-1 and 14 bands in mutant 5-2. Two new bands of molecular weights (MW) 114.04 and $44.70 \mathrm{kDa}$ were found in mutant 5-1, while only one band with $72.60 \mathrm{kDa}$ were disappeared in the mutant patterns as compared with the control.

Table 2. Mean squares from analysis of variance for six characters of nine wheat genotypes grown in the two seasons of 2003/2004 and 2004/2005 and their combined analysis.

\begin{tabular}{|cccccccc|}
\hline Seasons & D.f. & $\begin{array}{c}\text { Plant } \\
\text { height }\end{array}$ & $\begin{array}{c}\text { Spike } \\
\text { length }\end{array}$ & $\begin{array}{c}\text { No. of } \\
\text { spikes/ } \\
\text { Plant }\end{array}$ & $\begin{array}{c}\text { No. of } \\
\text { grains/ } \\
\text { spike }\end{array}$ & $\begin{array}{c}1000- \\
\text { grain } \\
\text { weight }\end{array}$ & $\begin{array}{c}\text { Grain } \\
\text { yield/ } \\
\text { plant }\end{array}$ \\
\hline $2003 / 2004$ & 8 & $303.39^{* *}$ & $2.84^{* *}$ & $65.02^{* *}$ & $267.03^{* *}$ & $24.12^{* *}$ & $1597.80^{* *}$ \\
$2004 / 2005$ & 8 & $276.30^{* *}$ & $2.32^{* *}$ & $31.73^{* *}$ & $392.81^{* *}$ & $19.87^{* *}$ & $640.14^{* *}$ \\
Combined & 8 & $286.78^{* *}$ & $2.53^{* *}$ & $46.70^{* *}$ & $323.25^{* *}$ & $19.82^{* *}$ & $1058.86^{* *}$ \\
\hline
\end{tabular}

** $\mathrm{P}<0.01$

Arab Univ. J. Agric. Sci., 15(2), 2007 
Table 3. Mean data of the nine wheat genotypes for six characters in two seasons and their combined.

\begin{tabular}{|c|c|c|c|c|c|c|c|c|c|}
\hline \multirow[b]{2}{*}{ Genotypes } & \multicolumn{3}{|c|}{ Plant height } & \multicolumn{3}{|c|}{ Spike length } & \multicolumn{3}{|c|}{ No. of spikes/plant } \\
\hline & $\begin{array}{l}2003 / \\
2004 \\
\end{array}$ & $\begin{array}{l}2004 / \\
2005\end{array}$ & Com. & $\begin{array}{l}2003 / \\
2004\end{array}$ & $\begin{array}{l}2004 / \\
2005\end{array}$ & Com. & $\begin{array}{l}2003 / \\
2004\end{array}$ & $\begin{array}{l}2004 / \\
2005 \\
\end{array}$ & Com. \\
\hline Sids 5 & 100.83 & 96.50 & 98.60 & 19.40 & 18.96 & 19.18 & 2.30 & 2.55 & 2.42 \\
\hline Mutant 5-1 & 79.60 & 78.70 & 79.10 & 20.50 & 20.53 & 20.51 & 11.80 & 10.06 & 10.93 \\
\hline Mutant 5-2 & 78.66 & 78.50 & 78.50 & 18.53 & 18.56 & 18.55 & 3.73 & 3.80 & 3.76 \\
\hline Sids 6 & 98.53 & 99.20 & 98.90 & 18.70 & 18.20 & 18.45 & 2.30 & 2.22 & 2.26 \\
\hline Mutant 6-1 & 77.53 & 79.20 & 78.40 & 20.56 & 20.13 & 20.35 & 12.33 & 9.00 & 10.66 \\
\hline Mutant 6-2 & 80.40 & 79.90 & 80.10 & 18.70 & 18.76 & 18.72 & 3.53 & 3.60 & 3.56 \\
\hline Sids 7 & 97.23 & 97.40 & 97.40 & 18.46 & 20.30 & 18.48 & 2.50 & 2.55 & 2.52 \\
\hline Mutant 7-1 & 79.73 & 77.40 & 78.50 & 20.73 & 20.30 & 20.51 & 12.40 & 9.13 & 10.76 \\
\hline Mutant 7-2 & 78.06 & 78.30 & 78.10 & 18.60 & 18.73 & 18.66 & 3.20 & 3.30 & 3.25 \\
\hline L.S.D.(0.05) & 2.55 & 1.54 & 1.50 & 0.92 & 1.27 & 0.68 & 1.04 & 0.62 & 0.68 \\
\hline \multirow[b]{2}{*}{ Genotypes } & \multicolumn{3}{|c|}{ No. of grains/spike } & \multicolumn{3}{|c|}{ 1000-grain weight } & \multicolumn{3}{|c|}{ Grain yield/plant } \\
\hline & $\begin{array}{l}2003 / \\
2004 \\
\end{array}$ & $\begin{array}{l}2004 / \\
2005 \\
\end{array}$ & Com. & $\begin{array}{l}2003 / \\
2004 \\
\end{array}$ & $\begin{array}{l}2004 / \\
2005 \\
\end{array}$ & Com. & $\begin{array}{c}2003 / \\
2004 \\
\end{array}$ & $\begin{array}{l}2004 / \\
2005 \\
\end{array}$ & Com. \\
\hline Sids 5 & 112.33 & 114.66 & 113.50 & 56.33 & 56.33 & 56.33 & 20.16 & 20.03 & 20.10 \\
\hline Mutant 5-1 & 91.66 & 88.33 & 90.00 & 61.00 & 61.66 & 61.33 & 59.43 & 49.53 & 56.36 \\
\hline Mutant 5-2 & 88.93 & 88.47 & 88.79 & 60.66 & 59.33 & 60.00 & 18.54 & 18.54 & 18.54 \\
\hline Sids 6 & 112.66 & 113.00 & 112.83 & 59.66 & 59.66 & 59.66 & 16.93 & 16.99 & 16.96 \\
\hline Mutant 6-1 & 93.33 & 94.00 & 93.66 & 57.66 & 57.66 & 57.66 & 66.75 & 45.98 & 56.36 \\
\hline Mutant 6-2 & 92.60 & 92.00 & 92.30 & 63.66 & 62.66 & 63.16 & 20.46 & 20.23 & 20.34 \\
\hline Sids 7 & 110.33 & 117.33 & 113.83 & 56.66 & 56.66 & 56.66 & 18.47 & 19.93 & 19.21 \\
\hline Mutant 7-1 & 101.33 & 101.66 & 10150 & 57.33 & 54.66 & 56.00 & 68.14 & 49.08 & 58.61 \\
\hline Mutant 7-2 & 99.26 & 99.56 & 99.41 & 63.66 & 59.00 & 61.33 & 18.81 & 19.12 & 18.96 \\
\hline L.S.D.(0.05) & 5.97 & 6.28 & 5.07 & 3.45 & 5.07 & 4.16 & 4.64 & 3.18 & 2.95 \\
\hline
\end{tabular}

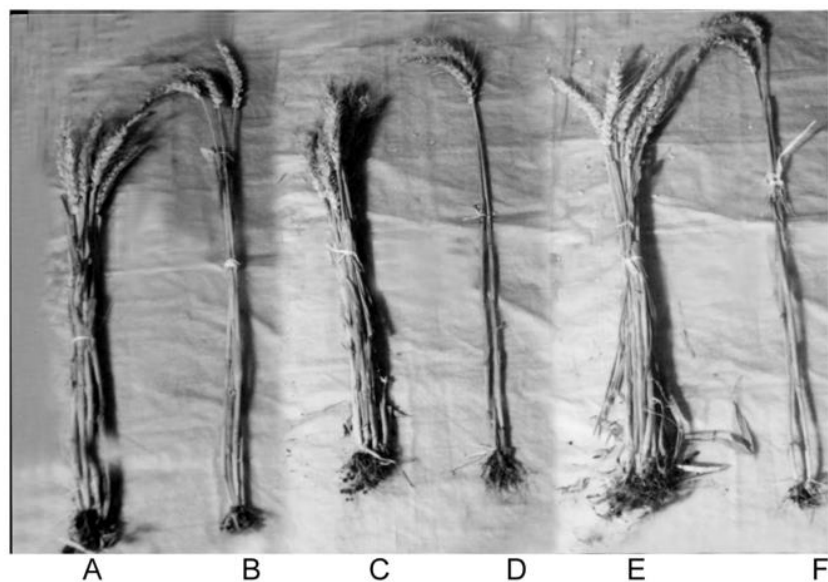

Fig. 1. Plant samples of the varieties Sids5 (B), Sids6 (D) and Sids7 (F) as compared to mutant lines 5-1 (A), 6-1 (C) and 7-1 (E). 


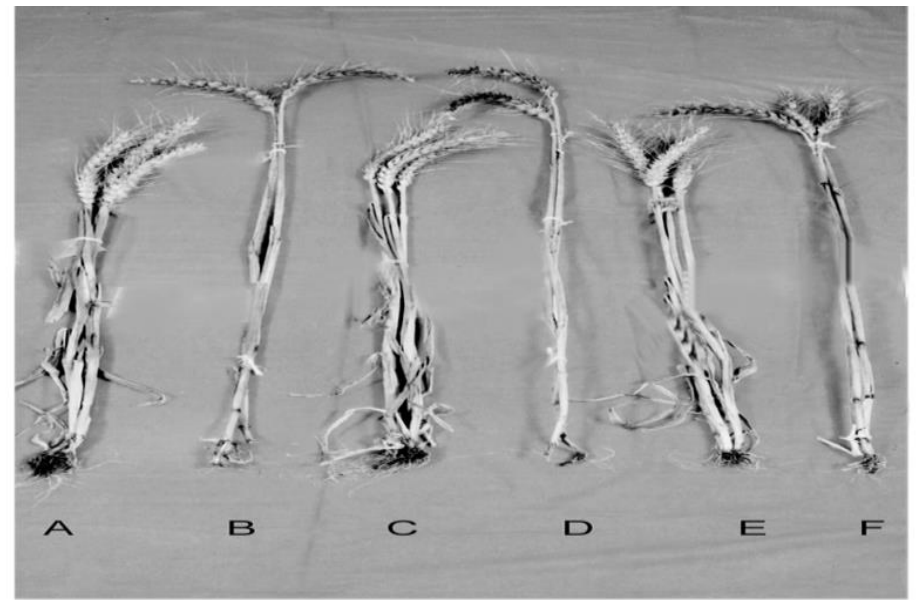

Fig. 2. Plant samples of the varieties Sids5 (B), Sids6 (D) and Sids7 (F) as compared to mutant lines 5-2 (A), 6-2 (C) and 7-2 (E)

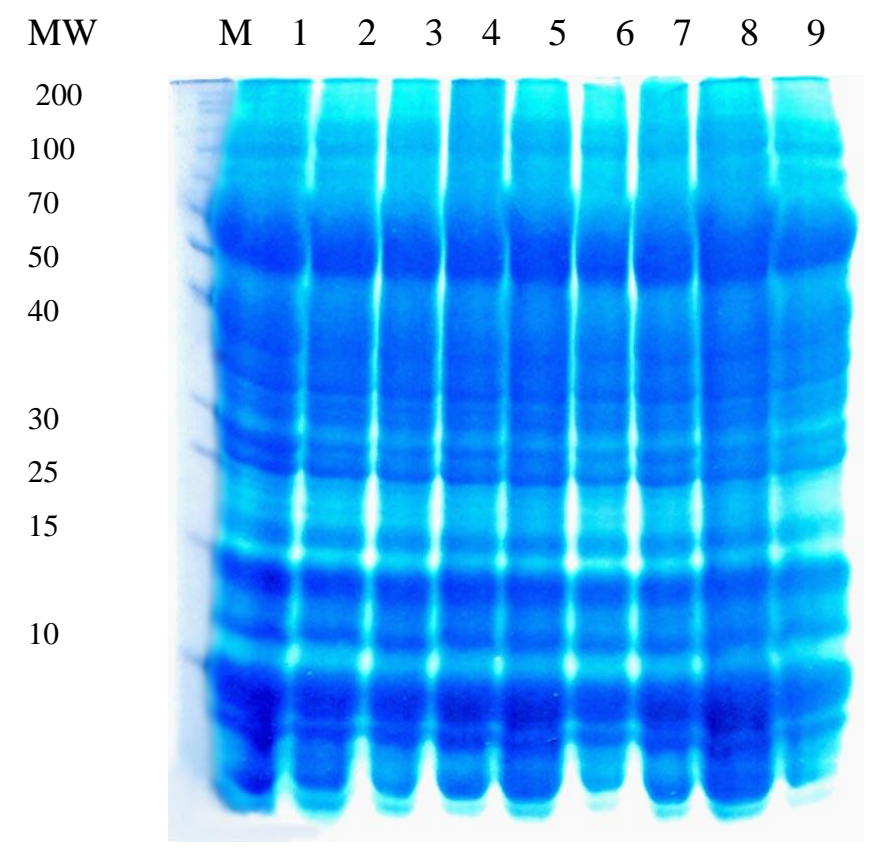

Fig. 3. Electrophoretic profiles of water-soluble proteins in grains of three varieties of wheat Sids5, Sids6 and Sids7 (lanes 1, 4 and 7, respectively), and their mutant lines 5-1, 5-2, 6-1, 6-2, 7-1 and 7-2 (lanes 2, 3, 5, 6, 8 and 9, respectively). M: marker proteins 
Table 4. Densitometric analysis of grain water-soluble proteins from SDS-PAGE shows band number and molecular weight (MW) for three varieties of wheat and their six mutants after irradiation by gamma-rays.

\begin{tabular}{|c|c|c|c|c|c|c|c|c|c|c|}
\hline \multicolumn{2}{|c|}{ Bands } & \multicolumn{9}{|c|}{ Genotypes } \\
\hline \multirow{2}{*}{ No. } & \multirow{2}{*}{$\begin{array}{l}\text { MW } \\
\mathrm{kDa}\end{array}$} & \multicolumn{3}{|c|}{ Sids5 } & \multicolumn{3}{|c|}{ Sids6 } & \multicolumn{3}{|c|}{ Sids7 } \\
\hline & & $\mathrm{C}$ & M 5-1 & M 5-2 & $\mathrm{C}$ & M 6-1 & M 6-2 & $\mathrm{C}$ & M 7-1 & M 7-2 \\
\hline 1 & 114.04 & - & + & - & - & - & + & - & + & + \\
\hline 2 & 106.32 & + & + & + & - & + & - & - & + & + \\
\hline 3 & 98.82 & + & + & + & + & + & + & + & + & + \\
\hline 4 & 87.82 & - & - & - & - & - & - & - & + & + \\
\hline 5 & 72.60 & + & - & - & - & - & - & - & - & - \\
\hline 6 & 64.14 & + & + & + & + & + & + & + & + & + \\
\hline 7 & 44.70 & - & + & - & + & - & - & + & - & + \\
\hline 8 & 41.55 & - & - & - & - & - & - & - & - & + \\
\hline 9 & 38.49 & + & + & + & + & + & + & + & + & + \\
\hline 10 & 35.17 & + & + & + & + & + & + & + & + & + \\
\hline 11 & 30.08 & + & + & + & + & + & + & + & + & + \\
\hline 12 & 27.86 & + & + & + & + & + & + & + & + & + \\
\hline 13 & 24.39 & - & - & - & + & - & - & - & - & - \\
\hline 14 & 21.36 & + & + & + & + & + & + & + & + & + \\
\hline 15 & 17.77 & + & + & + & + & + & + & + & + & + \\
\hline 16 & 14.50 & + & + & + & + & + & + & + & + & + \\
\hline 17 & 11.90 & - & - & - & - & - & - & - & + & - \\
\hline 18 & 11.12 & + & + & + & + & + & + & + & + & + \\
\hline 19 & 9.75 & + & + & + & + & + & + & + & + & + \\
\hline 20 & 8.26 & + & + & + & + & + & + & + & + & + \\
\hline 21 & 7.45 & + & + & + & + & + & + & + & + & + \\
\hline & bands & 15 & 16 & 14 & 15 & 14 & 14 & 14 & 17 & 18 \\
\hline
\end{tabular}

The variety Sids6 showed 15 bands in its pattern, while their two mutant patterns manifested 14 bands. Two protein bands with MW 106.32 and $114.04 \mathrm{kDa}$ were presented in mutant 6-1 and mutant 6-2 respectively comparing with the control. Meanwhile, one band with $44.70 \mathrm{kDa}$ was found in the control but disappeared in the mutant patterns. Concerning the variety Sids7, it revealed 14 bands in its control pattern, while it gave 17 and 18 bands in the patterns of mutants $7-1$ and 7-2, respectively. All protein bands of control pattern were found in the mutant patterns except band of $44.70 \mathrm{kDa}$ which disappeared in mutant 7-1. On the other hand, three bands of 114.04, 106.32 and 87.82 $\mathrm{kDa}$ appeared in mutants 7-1 and 7-2 comparing with the unirradiated plants. Also, one new band of $11.90 \mathrm{kDa}$ was found only in the pattern of mutant 7-1, and another protein band with MW of $41.55 \mathrm{kDa}$ was only presented in electrophoretic pattern of mutant 7-2.

The results showed that each variety has its own electrophoretic protein patterns. After irradiation, five bands appeared with molecular weights of $114.04 \mathrm{kDa}$ in the four mutant lines 5-1, 6-2, 7-
1 and 7-2; $106.32 \mathrm{kDa}$ in three mutant lines 6-1, 71 and $7-2 ; 87.82 \mathrm{kDa}$ in two mutant lines $7-1$ and $7-2 ; 44.70 \mathrm{kDa}$ in mutant line 5-1 and $11.90 \mathrm{kDa}$ in mutant line $7-1$. On the other hand, three protein bands were disappeared after irradiation as follow; band with $72.60 \mathrm{kDa}$ in two mutant lines 5-1 and 5-2; band with $44.70 \mathrm{kDa}$ in three mutant lines 6-1, 6-2 and 7-1 and band with $24.39 \mathrm{kDa}$ in two mutant lines 6-1 and 6-2.

The results of protein electrophoretic patterns for Sids5 and its mutants 1 and 2 (Figure 3 and Table 4) coincided with the combined mean values of grain yield per plant for the two seasons of 2004 and 2005 (Table 3). The number of bands in protein pattern for Sids5 plants of control was 15 bands and the mean value of grain yield per plant was $20.10 \mathrm{~g}$. Meanwhile, the number of bands in mutant 5-1 protein pattern increased to 16 bands and the mean value of grain yield increased to $56.36 \mathrm{~g}$. Also, the number of protein bands in mutant 5-2 was decreased to 14 bands and the mean value of grain yield per plant was decreased to 18.54 g. Similar results were found for the three other traits of spike length, number of spikes per 
plant and 1000-grain weight. Similar relations were found between number of bands in the patterns of Sids6 (15, 14 and 14 bands) and the combined mean values of plant height $(98.90,78.40$ and $80.10 \mathrm{~cm}$.) and number of grains per spike (112.83, 93.66 and 92.30), respectively.

The variety Sids7 appeared to be the most tolerant variety against radiation which manifested the highest number of new protein bands after irradiation, four bands in each of mutant line 7-1 and mutant line 7-2. These results coincided partially with those of grain yield per plant for Sids 71 in which it showed the highest combined mean value of grain yield per plant 58.61 g (Table 3). The above results lead to conclude that there are positive relations between number of bands in the protein patterns of Sids5 and Sids6 and their mutant lines, and most of agronomic and yield traits. The results are in agreement with those of Scoles (1999) who reported that radiation creates mutations in the genes of crop plants, and of Little (2000) who revealed that the radiation inactivate genes leading to alter metabolic pathways or repressors whose absence leads to enhanced production of metabolites improving varieties. Melchinger et al (1992) reported that biochemical markers have been used to estimate the level of genetic variability in plant populations. Hussien and Stegemann (1978) showed that SDS-PAGE of grain proteins was a rapid method to screen varietals differences in wheat.

\section{REFERENCES}

Abdel-Tawab, F.M.; A.A. El-Seoudy; M.A. Rashed and A. Bahieldin (1993). Enzyme diversity and identification of wheat cultivars. Annals Agric. Sci., Ain-Shams Univ., Egypt, Sp. Issue, 2: 465-475.

Al-Kobaisi, N.M.; I.F. Ibrahim; A.A. Kraibat and A.K. Kadham (1997). Induce mutation for leaf rust and lodging resistance in wheat (Triticum aestivum L.). Crop Improvement, 24: 256-268.

Camargo, C.E.; A.N. Tulmann; A.W.P. Ferreira; J.C. Felicio; J.L. Castro and A.J. Pettinelli (1997). New wheat (Triticum aestivum L.) genotypes obtained by gamma irradiation. Scientia Agricola, 54: 195-202.

Gheorghe, V. and G. Burloi (1992). Behavior of some winter wheat lines, obtained following X-ray treatment in comparative traits. Agronomie, 35: 712.

Hussien, K.R.F. and H. Stegemann (1978). Comparison of proteins from wheat kernels by various electrophoresis methods in polyacrylamide. J. Agro. and Crop Sci., 14: 668-78.

Laemmli, U.K. (1970). Cleavage of structural proteins during the assembly of the head bacteriophage T4. Nature, 227: 680-685.

Little, J.B. (2000). Radiation-induced genomic instability. Int. J. of Rad. Biol., 74: 663-671.

Melchinger, A.E.; J. Boppenmaier; B.S. Dhillon; W.G. Pollmer and R.G. Herrmann (1992). Genetic diversity for RFLPs in European maize inbreds. II. Relation to performance of hybrids within versus between heterotic groups for forage traits. Theor. Appl. Genet., 84: 672-681.

Muluszynski, M.; K. Nichterlein; L. Van Zanten and B.S. Ahloowalia (2002). Officially released mutant varieties. The FAO/IAEA Data Base. Mut. Breed. Rev., 12: 1-84.

Sakin, M.A.; A. Yildirim and S. Gokmen (2004). The evolution of agronomic traits of durum wheat (Triticum aestivum L.) mutants. Pakistan J. of Biological Sci., 7: 571-576.

Santana, T.C. and M.C.T. Cervants (1996). Selection of high yielding wheat lines from irradiated composites. Agrociencia, 30: 509-514.

Scoles, G. (1999). Mutagenesis and food crops. Mut. Breed. Newsletter, 2: 12-17.

Selim A.H. (2000). Evaluation of Some Heat Tolerant Wheat Germplasms for Yield and Yield Quality. p. 64. Ph.D. Thesis, Fac. of Agric., Ain Shams Univ., Cairo.

Snedecore, G.W. and W.G. Cochran (1969). Statistical Methods. $6^{\text {th }}$ Ed., p. 169. Ames. Iowa State Univ. Press. U.S.A.

Sobieh El-S.S. (2002). Induction of short calm mutants for bread wheat by using gamma rays. Arab J. of Nuclear Sci. and Applications, 35: 309-317.

Stegemann, H.; A.E.T. Shehata and M. Hamza (1980). Broad bean (Vicia faba L.). Electrophortic studies on seeds of some German and Egyptian cultivars. J. Agronomy and Crop Sci., 149: 447 453.

Tulmann, N.A.; C.E. Camargo; J.L. Castro and A.W.P. Ferreira (2001). Evaluation of "Anahuac" wheat mutant lines for aluminum tolerance. Euphytica, 120: 339-343.

Vombergar, B.; B. Javarnik and L. Vaupotic (1984). SDS-PAGE of all proteins in wheat varieties. Zbornik Biotechniske Fakultate Univerze Edvara Kordelja Vljubljani, Kometijstvo, 41: 29-36.

Waller, R.A. and D.B. Duncan (1969). A bias rules for the symmetric multiple comparison problems. J. Amer. Stat. Assoc., 13: 1485-1509. 